\title{
CONCEPTUAL ALIGNMENTS AND DEBATES IN THE STUDY OF MOBILITY AND MIGRATION: AN INTRODUCTION
}

\author{
Triinu Ojamaa
}

Senior Research Fellow

Estonian Cultural History Archives

Estonian Literary Museum, Estonia

Email: triinu.ojamaa@kirmus.ee

\section{Leena Kurvet-Käosaar}

Associate Professor of Cultural Theory

University of Tartu, Estonia

Senior Research Fellow

Estonian Cultural History Archives

Estonian Literary Museum, Estonia

Email:leena.kurvet-kaosaar@ut.ee

\begin{abstract}
The introduction to the first part of the special issue of Folklore: Electronic Journal of Folklore, titled "On the Move: Migration and Diasporas", situates the articles included in the issue within theoretical discussions of significant factors that have influenced population movements, formation of diaspora communities, and diversification of the transnational life style during the past decades. The introduction discusses the genealogy of the concepts of diaspora, transnationalism, migration, and mobility, also drawing attention to their simultaneous circulation within the inter- and cross-disciplinary field today. Both forced and voluntary forms of migration are addressed. The relevance of the contributions of the current issue to larger tendencies and theoretical debates on mobility and migration is outlined. The study of migration and mobility constitutes a vast area of academic inquiry, yet there is not enough research on migration processes in Eastern Europe and the post-Soviet countries. The articles fill this gap, engaging in a variety of issues, theoretical and methodological approaches, and diverse regions and historical contexts. These include historical transnational commuting practices, the effects of status shifts from voluntary to forced migration, the inadequacy of contemporary ICT-based communication means in comparison with face-to-face encounters, modes and strategies of (transatlantic) transnational identity, affective economy of migration, including its traumatic impact, and relevance of the researcher's positioning in terms of the national culture of homeland and host country. Many contributions highlight the important role of
\end{abstract}


sociality in managing migration and mobility, and in so doing, also diversify and contest central conceptual paradigms within the field.

Keywords: diaspora, forced and voluntary migration, mobility, sociality, transnationalism

\section{CURRENT TRENDS IN THE STUDY OF MOBILITY AND MIGRATION}

With a continuous increase in the global number of international migrants, which constituted 271.6 million or close to 3.5 percent of the world's population in 2019 (see Migration Data Portal), the study of the interrelated areas of mobility, migration, diaspora, transnationalism, and globalization forms a vibrant field of research. Characterized by inter- and transdisciplinary nature, it is also marked by the continuous evolvement of distinct disciplinary traditions and related methodological premises (see, e.g., Brettell \& Hollifield 2015a [2000]; Sirkeci et al. 2019; Vargas-Silva 2012; White 2016). The scholarly study of migration, marked by first systematic data collection initiatives, is believed to have emerged from the contexts of eighteenth-century mass mobility in Europe, transatlantic mass migrations of the nineteenth century, and northern Chinese migrations to Manchuria in the twentieth century (Harzig \& Hoerder 2009: 54-55). Conceptualizations of a more comprehensive nature of migration can be traced back to the emergence of sociology at the turn of the nineteenth century, a time characterized by mass migration of both European and intercontinental scale. In time shedding the eugenic perspective, characteristic of the early perspectives of migration, sociology as a field has always incorporated a focus on migration and mobility (FitzGerald 2015 [2000]: 115). However, in many disciplines, such as, for example, demography, geography, and political science, migration and mobility have emerged as important areas of research only over the recent two or three decades. Even in anthropology, a discipline that together with sociology holds a leading position in contemporary research on migration and mobility, an understanding of culture as a bounded, territorialized, stable, and homogeneous entity dominated until the 1960s, discouraging the study of cultural change and "forms of social organization that are characteristic of both the migration process and the immigrant community" (Brettell 2015 [2000]: 148-149). Diaspora studies, a subfield of the study of migration and mobility, in its current format representing an array of "multiple and interlinked social science and humanities approaches", consolidated as a field only in the early 1990s (Stierstorfer \& Wilson 2018: xvi, xiii), followed in less than a decade by a transnational paradigm shift in migration studies (see, e.g., Portes \& Guarnizo \& Landolt 1999; Vertovec 2009), prevalent in the current perception of the field. 
Two trends that characterize the study of migration and mobility today in its different variations and theoretical and methodological advances are, firstly, conceptual alignments and debates that can be traced in particular around the concepts of diaspora and transnationalism and, secondly, the furthering of the development of inter- and transdisciplinary paradigms and research initiatives. Thus, for example, in the introduction to A Companion to Diaspora and Transnationalism, the editors Ato Quayson and Girish Daswani (2013: 2) propose to organize different forms and implications that derive from the vast movements of "populations, ideas, technologies, images, and financial networks" of today's world around the both overlapping and clashing conceptual frameworks of diaspora and transnationalism, as well as that of globalization. Some of the characteristic features of diaspora Quayson and Daswani provide (ibid.: 3 ), such as "the time-depth of dispersal and settlement in other locations" and "the development of a myth of the homeland", match the characteristic features of diaspora contained in the influential paradigm of diaspora outlined by Robin Cohen (1997: 26) which, in turn, is based on the work of William Safran (1991). However, while Cohen's emphasis is on homogeneity and strength of ethnic group consciousness, in its current conceptualizations, diversity and even conflict - in terms of responses to the homeland and host nation as well as in relation to class structure and "forms of material and emotional investment" in the diaspora community - are highlighted (Quayson \& Daswani 2013: 3).

As several scholars have pointed out, the concept of transnationalism started evolving by way of escaping the "methodological nationalism" (Wimmer \& Glick Schiller 2002) characteristic of the study of migration. It refers to the "often unstated assumption that national society or national state is the 'natural' unit of analysis and of data collection" (Faist 2013: 457), extending both to the understanding of the homeland but, even more importantly, to the understanding of host countries, in particular in terms of assimilation. While retaining a focus on communal attachments, the transnationalist perspective moves away from the exclusively ethnic bias and widens the criteria of communal identification to the categories of difference including, for example, that of race, class, sexuality, schooling, and professional and political affiliation (Faist 2013: 457; Quayson \& Daswani 2013: 4). The transnational perspective has influenced the way in which diaspora is conceptualized today, including an emphasis on "the circuits and circulations that fundamentally undergird migrant social identities across borders" (ibid.: 5), which Cohen touched upon but did not emphasize to the degree it is highlighted in transnationally oriented analyses today. According to the contemporary understanding of diaspora, it is not a concrete and stable entity but a "series of contradictory convergences of peoples, ideas, and ... cultural orientations" (ibid.: 4). 
Steven Vertovec has described the transnational turn in the anthropology of migration as a shift in focus "from groups in specific localities to groups and their activities as they engage cross-border, multi-local processes and practices" (Vertovec 2007: 968). The conceptual frame of transnationalism also expands on what is included in terms of mobility: the focus not only on groups of people but as importantly on "notions of citizenship, technology, forms of multinational governance, and the mechanisms of global markets" (Quayson \& Daswani 2013: 4), all of which are also part of the process of identity formation. One of the central defining features of the transnational perspective, characterizing both the identity formation processes and the ways in which transnationalism is practiced, is the notion of simultaneity, elaborated by Peggy Levitt and Nina Glick Schiller as a key feature of the transnational social field. Taking (transnational) mobility as their starting point, Levitt and Schiller (2004: 1011) expand on the conceptual frame of society, detaching it from the boundaries of a single nation state and proposing, instead, as the key characteristic of migrant experience, "a simultaneity of connection" that is neither "full assimilation" nor "transnational connection but some combination of both". The concept of simultaneity has, however, also been subject to criticism on the grounds of its realizability in real life or even failure on all accounts (see, e.g., Werbner 2013; Quayson \& Daswani 2013: 106-124).

Like conceptual renewal processes in diaspora studies, migration studies that has been related to methodological nationalism has undergone a number of shifts aiming, for example, to transcend both the "disciplinary, geographical, and methodological limitations" and the formerly exclusive nature of scientific and scholarly investigation of migration (Gold \& Nawyn 2013: 3). The diversification of researchers in terms of "nationality, class, gender, religion, race, life experience, and sexual identity" leads to the positing of new research questions, adhering to loyalties and proposing perspectives absent in the earlier research tradition of migration (ibid.: 3). The focus on "the field of international migration per se" highlights the "interdisciplinary, eclectic, complementary and integrative" nature of research in the field as well as its "competing and contradictory" nature (ibid.: 3; Brettell \& Hollifield 2015b [2000]: 2-3). The task of "re-ground[ing] - or "reboot[ing]" - migration theory" (Favell 2015 [2000]: 318 ), considered to be of importance by the majority of critical consideration in the field may vary in essence. In addition to the perhaps most widely adopted transnationalist perspectives, revisions may include heightened attention to the distinctive features of different geopolitical and historical contexts that may vary to a considerable extent in European and American or Australian context. With regard to recent migration trends in Europe, aspects to consider include the citizenship of the European Union, in force since 1993, the EU enlarge- 
ment of 2004 and 2007, and the following new migration flows, dominantly from the former Eastern bloc and the Baltics, which defy "straight-line models of immigration to citizenship", constituting, rather, complex and often circular forms of transnational migration (Favell 2015 [2000]: 325). Academic research on migration is also increasingly geared toward contributing to policymaking processes on the national and international level as well as public debates and discussions on the subject.

\section{MIGRATION AND SOCIALITY}

Compiled in the spirit of inter- and cross-disciplinary dialogues, characteristic of and encouraged within the field, the first part of the special issue of Folklore: Electronic Journal of Folklore, "On the Move: Migration and Diasporas", brings together researchers representing a variety of fields of the humanities and social sciences: sociology, anthropology, folklore studies, history, and life writing studies, supplemented by the work of literary scholars and linguists. The topics addressed in this issue include different waves of migration, the current migration crisis, gendered aspects of migration, transnationalism, and social and cultural adaptation in host countries from both historical and contemporary perspectives, across an array of socio-political and cultural contexts. The contributions of the current volume focus on migration dominantly from the perspective of the individual, and highlight, in particular, the crucial importance of the ways in which social engagements and bonds and communication networks are formed and function (or fail to function) on individual and collective levels in the context of forced and voluntary migration. All this attests to the importance of the notion of sociality as "the interactional core of all human life" (Anderson 2015: 100; Toren 2012: 48) for migration research. Defined as "a dynamic matrix of relations through which persons are constituted in interactive and mutually constitutive ways" (Long \& Moore 2013: 19), sociality is viewed as harbouring the potential of "emerging relational fields" and relying on improvisational dimensions of communication that include ambivalences, impasses, and failures characteristic of human relations (Anderson 2015: 97, 100; Long \& Moore 2013: 2). With regard to the field of migration and diaspora studies, of importance here is the delineation of two strands of diaspora research provided by Quayson and Daswani who credit the work of Cohen (1997, 2008), Dufoix (2008) as well as that of Brah (1996) with the outlining of social typologies of diasporas characteristic of the social sciences approach to the study of migration and diaspora. Another strand is exemplified by the work of Marianne Hirsch (1997, 2012) on postmemory and the work of Paul Gilroy 
(1993) and James Clifford (1997), enriching the academic debates on diaspora by introducing questions of the nature and the role of memory, specificities of memory processes, affective aspects of dispersal and re-settlement and "the intersubjectivities of social identity" (Quayson \& Daswani 2013: 8). While it is primarily the latter thread that is credited with introducing questions of sociality and relationality into diaspora and migration studies, it is also Brah's (1996) notion of diaspora space characterized by the centrality of "social and moral relationships that continually structure and restructure it" (ibid.: 4) that makes a significant contribution to such a perspective. With regard to the current scene of mobility, applicable dominantly to its voluntary forms, the emergence of a new kind of migrating population has been traced, "composed of networks, activities and patterns of life that encompass both their host and home societies" (Glick Schiller \& Basch \& Blanc-Szanton 1992: 1). This is related to the inclusion of different forms of mobility, in the contemporary world particularly relevant in terms of work-related commuting practices expanding the concept of labour migration as well as virtual communication possibilities facilitated by information and communication technology (ICT) development that blurs the boundaries between different forms of mobility.

\section{NAVIGATING THEORIES: INTRODUCTION TO THE ARTICLES}

The current special issue "On the Move: Migration and Diasporas" includes seven case studies on migration and their social and cultural consequences in different regions of the world: Europe, North America, the Middle East, and the Far East, covering diverse historical contexts from the nineteenth century to the present. Both migration forms - voluntary and forced - are under discussion. Voluntary migration concerns primarily labour migration, but in addition to the main push factors such as unemployment or low wages also the emotional status of migrants has been addressed. Forced migration and its consequences are treated based on examples of various wars of the twentieth century: World War II, and the armed conflicts in Kosovo and Syria. The authors analyse different situations where war destroys cultural traditions, separates kin or places children face-to-face with violence, which causes traumatic experiences at both group and individual level. Several articles also analyse how and why the members of one ethnic or national group leave their country in some cases forcibly and in some others voluntarily. Finally, the studies presented in the current volume demonstrate how one migration form can shift to another, and that the boundary between voluntary and forced is not always clear. 
In the article "The Kosovo Conflict and the Changing Migration Patterns of the Gorani Community: Continuities and Shifts", Ivaylo Markov takes under observation the Gorani people, defining them as an "archetypal migrant community", thus referring to their everlasting "being-on-the-move" that has been caused by various reasons and realized in different ways. Markov gives an overview of the dynamics of migration patterns specific to the Gorani from the times of the Ottoman Empire until the last two decades. In the context of the special issue Markov's case study can be regarded unique. It addresses the migration practices of an ethnic group for whom labour migration has been an integral part of everyday life for several centuries. Historically, this was a model where men did seasonal work away from home in neighbouring areas, earning living for their kin; their wives and other family members stayed in their home villages. As Markov mentions, this model is sometimes defined as the "Balkan culture of migration" because, in addition to the Gorani, it was practiced by several Balkan peoples. One can say that with some reservations, the "Balkan model" is comparable to the practice of commuting, which has developed in Northern Europe in the recent decades. Workers' active crossborder mobility is characteristic of all three Baltic countries and also Poland (see, e.g., Hazans 2003; Telve 2017). Even if everyday practices are not exactly the same, these migration patterns are in principle comparable. However, we refer to this parallel primarily to highlight one important difference between them. Commuters in the Baltics are often criticized because of the resulting labour shortage in the homeland, influx of migrant workers from outside the European Union, falling birth rates, etc. In addition to that, they can be characterized as "comfort migrants" who are looking for greener pastures. Markov's study clearly shows the opposite attitude towards labour migrants in the Gorani community. He describes how labour migrants were respected by their families who sent them away and received with traditional ceremonies as the members of the community who ensured the welfare of their kin. The main purpose of Markov's study is to highlight the tendencies distinctive to migration patterns which began to develop after the Kosovo armed conflict in 1998-1999 - a pivotal event throughout the region. As many people were forced to abandon their homes, it is defined as "mass exodus"; the same term is often used to refer to the wave of mass migration caused by World War II from Eastern Europe and the Baltic countries to the West. In his study, Markov shows the replacement of men's migration by family migration and the expansion of the number of countries of destination: in addition to the Balkans, the Gorani began to leave for Switzerland, Germany, France, Luxembourg, Sweden, Finland, etc., melting into the mass of labour migrants who had reached there in the wake of the collapse of the Eastern Bloc in the 1990s. 
Desislava Pileva examines changes in the migration practices of four mixed families following the outbreak of an armed conflict in Syria in 2011. Her article "From Mobility to 'Exile'. Shifting Co-Presence: Narratives of Bulgarian-Syrian Families in Bulgaria" is based on the interviews with family members where one of the spouses is a Syrian who came to study in Bulgaria during the socialist period. The roots of this article can be found in Pileva's earlier study "Images of 'Our Foreign Friends': Representations of Students from the Middle East and Africa in the Bulgarian Newspaper 'Student's Tribune' (1960s-1970s)" (Pileva 2017), which deals with foreign students' social and cultural adaptation and the interaction with some other ethnic groups. In the article published in this special issue, Pileva compares the ways the kin communicated and spent time together before and after the Syrian armed conflict. One can say that before and after in Pileva's research are not just adverbs but function like key concepts, the first of which refers to the possibility of being together physically and the second one to the lack thereof. The study demonstrates transition from one type of migration to another. Pileva highlights the change in the situation of Syrians, arguing that as a result of the military conflict the Syrians who voluntarily settled in Bulgaria have ended up more or less as exiles. Thus, their immigrant position has changed cardinally, they are not free to come and go any more and their normal communication with relatives is blocked. Pileva's study demonstrates that the hindered common activities and inhibited face-toface communication cannot be regarded as just individuals' personal problems; first and foremost, it means that the continuance of traditional Syrian lifestyle has been put under pressure. Pileva examines the substitution of physical presence for virtual presence or communication from a distance, briefly discussing whether the ICT tools can replace traditional forms of communication or merely supplement them. The answer is, in a sense, predictable - at least in cultures where physical presence and interaction are of great importance, virtual communication can only play a complementary role. We would like to highlight that in her study Pileva describes a new type of meeting opportunities the migrants use in a situation where the ordinary lifestyle no longer works. In connection with the war, Syrian refugees have reached Europe and many of them have been granted asylum, for example, in Sweden or Norway. In those third countries their Bulgarian relatives can visit them without any restrictions; it enables to re-establish the physical proximity. Thus, Pileva's study documents the emergence of a new communication channel at least partly in accordance with traditional norms. This tendency can be regarded as a novel topic in the study of migration.

In the article "Uncertainties of Transnational Belonging: Homeland Nationalism and Cultural Citizenship of Lithuanian Immigrants in the USA" Vytis 
Čiubrinskas takes under comparative observation the representatives of two different migration waves, the first of which was triggered by World War II and the second one by the collapse of the Eastern Bloc in the 1980s-1990s. The article is based on several fieldwork trips and it can be considered an indepth treatment of his earlier study on Lithuanian immigrants, the purpose of which is to explore the ways of immigrant ethnification and inter-ethnic networking as post-socialist legacy transported to the USA from Eastern Europe (Čiubrinskas 2018). In the article published in the current special issue Čiubrinskas (2020) aims to demonstrate how the migrants of different waves - forced and voluntary - use their social ties and cultural resources, acquired under various political and historical circumstances, for coping with their transnational belonging. In order to achieve his goal, Čiubrinskas operates with two key concepts: homeland nationalism and cultural citizenship. These key concepts have proven to be effective tools for illuminating the differences in the coping strategies of the two waves in the context of transnational belonging. The semantic field of homeland nationalism is centred around the moral imperative according to which an immigrant must be devoted to his/her country of origin. For the representatives of the first wave of migration this functions as a guarantee, saving them from vanishing in the huge American melting pot. Cultural citizenship or moral economy used for networking with Eastern European immigrants is a concept Čiubrinskas applies to analyse the strategy of coping with marginalization of the second-wave immigrants. In his article, Čiubrinskas discusses the development of these strategies, showing that the roots of homeland nationalism and cultural citizenship are in different soils: the first strategy began to develop in the displaced persons' (DP) camps in the $1940 \mathrm{~s}$, and the second one can be regarded as a relic of the socialist period of Lithuania. We would like to draw attention to the historical overview of the development of exile Lithuanians' cultural and political principles in the DP camps built on the Nazi-free territory of Germany, outlined by Čiubrinskas. It deserves attention for at least two reasons: there is little research done on this (see also Hollo 2020) and, secondly, based on the experiences acquired by refugees and sociocultural ties of immigrants created in DP camps, they built up their lives after immigrating to third countries in the 1950s.

The article also contains several novel observations about the coping strategies and self-assertion of the representatives of post-socialist immigration wave. Čiubrinskas demonstrates how and why the new immigrants' networks get started, cross ethnic boundaries, and create a common environment or socalled one's own people's circles, which unite post-socialist immigrants from various countries. Čiubrinskas also shows how the transnational lifestyles of the two waves differ from each other and how this situation causes communication 
problems between them. Thus, he touches upon an important mentalityrelated issue that is also being discussed by immigrants outside the academia. The United States, similar to Canada, have large post-World War II Baltic diasporas that have expanded with thousands of compatriots since the 1990s. Representatives of the two waves perceive differences between "old" and "new" immigrants. One part strives to bridge them, claiming that they are all just Latvians/Lithuanians/Estonians, the other part recognizes differences but shares the opinion that this is not a barrier for communication. The third part prefers to communicate with the immigrants who belong to their own wave as Čiubrinskas demonstrates in his study, which can be regarded as a remarkable contribution to migration studies on the Central Eastern European region.

The article titled "Emotional State and Inequality among Lithuanian Emigrants" by Dainius Genys, Ilona Strumickienė, and Ričardas Krikštolaitis is based on a survey conducted in 2018; the group of respondents contained migrants from Lithuania whose regions of destination were Scandinavian countries, Great Britain, and Southern Europe. As it is known, emigration is commonly linked to unemployment, low wages, and poor living standards worldwide, and there is no reason for doubt that these factors also have a certain impact on emigration from Lithuania. However, the research team approaches these issues from a novel perspective of the emigrants' emotional state, which often remains in the background or is completely overshadowed by economic problems. Based on the results of 1,500 questionnaires, the researchers investigate whether the migrants feel needed or superfluous, happy or unhappy in their homeland, and what their attitudes towards their country of origin are. The study is largely driven by the thesis that the circumstances in which people do not have the opportunity to experience positive emotions can lead to serious social consequences. According to the authors, the negative emotions can hinder or even stop the process of knitting society as a unified social fabric. In other words, the underestimation of people's emotional state can turn out to be a national security risk. With that in mind, the results of the study would deserve not only the attention of the academic circle but also of the policy makers in Lithuania as well as in other Baltic states and in Eastern Europe in general. The study compares three cluster groups: the learning youth, precariat, and potential, which are differentiated on the basis of education, income, and employment. As a result of the survey, it becomes apparent that migrants are missing opportunities to formulate their emotions in public and to publicly discuss the reasons for leaving homeland. The migrants believe that if these opportunities existed, there would be less criticism of migrants and a better understanding of their problems by their compatriots at home. In turn, that would have a positive effect on the migrants' emotional state. On the other 
hand, the study shows that the migrants' citizen activeness is relatively low and the expectation that all problems should be resolved by the political order is, vice versa, high. The comparative analysis of three cluster groups reveals that the representatives of the potential group are somewhat more accustomed to contributing to the advancement of society than the representatives of the other groups; the potentials have a deeper awareness of their role as creators of public goods and well-being in society. It can be concluded that their relations with the country of origin are balanced better than those of the other groups. We would also like to highlight the fact that women dominate the potential group. The aim of the study is not to analyse the emotional state and attitude towards the country of origin on the basis of gender. Nevertheless, the results of the study suggest that women's emotional state may be better in comparison to that of men's who are dominating among the precariat. As migration is not exclusively male-dominated space and women migrate not only as family members (McDowell 2013; see also Markov 2020), gender-based approach to labour migration in the Baltic countries could be one possible line for further investigation.

In the post-World War II years, the goal of the Swedish public policy was to retain a homogenous Swedish culture. Almost all immigrants came from neighbouring countries and were expected to assimilate into the native Swedish population. In the middle of the $1960 \mathrm{~s}$, media debates began, in which some debaters demanded that the minorities should be allowed to promote their ethnic identity and culture, and some others advocated for assimilation. These debates turned the minority-related issues into an important political one. In the 1970s the situation changed due to the resolution of the Parliament, which stated that Sweden was no longer dominated by Swedish culture but was becoming a culturally pluralist society (Eckehart 2017: loc. 143) and also Swedish researchers became more interested in immigrants, including World War II refugees.

Maija Runcis' contribution to the special issue, "Estonian Diaspora in Sweden: An Analysis of the Collection "Life Destinies" at the Swedish Nordic Museum", can be placed in this context. Runcis demonstrates how the archival collection produces a narrative about World War II refugees of Estonian origin in Sweden, which underlines their adaptation to Swedish society at the expense of other elements of identity, most importantly their Estonian identity. The author questions the widespread view generated by several researchers that Estonians as well as other Baltic peoples represent a well-integrated immigrant group not only in Swedish multicultural society but in other Nordic countries as well (see, e.g., Raag 2004; Kyntäjä 1997). Runcis brings novelty to this discourse primarily due to its unique source material. In addition to 
interviews with exile Estonians, carried out by the Swedes as the representatives of dominant culture, the collection "Life destinies - Estonian diaspora in Sweden" also contains the interviewers' notes and commentaries on the situation in which the interview was conducted as well as the interviewees' manner of behaviour, outfit, home design, etc.

In the article titled "Traces of Trauma in Estonian Women's Life Narratives of World War II" Maarja Hollo deals with the mediation of the traumatic impact of witnessing warfare and the precarious escape journey to the West. She aims to identify the textual strategies and thematic accents employed for communicating experiences that can be interpreted as traumatic. Like Pileva (2020), who analyses immigrants' practices of communication and being together in two different periods - before and after the events of the Syrian war, Hollo also distinguishes two temporalities: secure and beautiful childhood before World War II and shook-up life order after the beginning of World War II, the escape to the West and the years spent in displaced persons' camps. Hollo claims that life narratives rarely contain detailed descriptions of traumatic experiences and discusses the possible reasons for that. She concludes that the Estonian tradition of self-referential storytelling does not facilitate the expression of traumatic experiences; there is no cultural model for elaborating or even naming this kind of experience. Hollo has chosen life narratives that can demonstrate how war draws a line between happy memories and memories that contain traumatic elements. But is this boundary always so uniform and the contrasts so obvious? The documentary "Coming Home Soon: The Refugee Children of Geislingen" (2018), produced by Helga Merits, can be used as an example for discussing this issue. The documentary is based on unique film clips made by Estonian amateur filmmakers during their flight and life in DP camps, various archival sources and memories of former refugee children who now are in the eighties. In their stories one can hear an echo of traumatic experiences similar to those analysed by Hollo: there was hunger, sickness, and death that turned the beautiful German town called Geislingen into a 'black hole' in the memory of a refugee girl. But there also was another side of life that made people remember the years spent at the camp as 'the best part of childhood' and the camp itself as 'a nice nest'. According to several former camp residents, the camp was a place of socialization, where young people learned how to cope with life abroad. Thus, one can also see in this documentary the emergence of the strategies analysed by Čiubrinskas (2020). Because of the current refugee crisis life in camps has once again become a topic of importance. In an interview for the Estonian Public Broadcasting, Merits said that thematically, her documentary fitted into the present day. But she also explained that there was much in Europe that was not yet talked about in connection with World War II and 
these marginalized or repelled memories moved from generation to generation; they had an effect on the individuals' way of thinking and self-identification. Merits concluded that making the past clear gave people freedom to look into the future (kultuur.err.ee 2019).

In the article "The Task of a Cultural Researcher: Telling the Story of Siberian Estonians" Anu Korb interprets the mission of a researcher based on her personal activities and experiences. In 1991-2016 she made sixteen academic fieldwork trips to Estonians living in Siberia to observe their folklore. In the introduction to the article, Korb gives a brief overview of Siberian Estonians' various migration practices in the nineteenth century and in the first decades of the twentieth century: voluntary emigration, deportation, and remigration are represented. Considering the status of Estonia in the nineteenth century, one can say that Korb's article is the only one in this special issue dealing with internal migration. ${ }^{1}$ Korb's study capitalizes on return migration, which gathered momentum when the Republic of Estonia was occupied by the Soviet Union during World War II. Referring to Kulu (1997) and Jürgenson (2015), Korb explains that the reasons for expatriation were often political and ideological: several return migrants became functionaries of the Communist Party, thus damaging the reputation of the representatives of Estonian eastern diaspora. The Estonian diaspora can be divided into two groups: the eastern diaspora (incl. Siberian Estonians) and the western diaspora consisting mainly of Estonians who fled to the West during World War II (see also Runcis 2020 and Hollo 2020). According to Korb, the attitudes of Estonians in the homeland towards these groups are different: in general, the western diaspora is viewed more positively than the eastern one. Claiming this, Korb highlights the fact that has been rarely addressed in research on Estonian diaspora. Of particular interest here, however, is the fact that at the global level, the stigmatization of migrants is mostly discussed in the context of their new country of residence (e.g. Brown 1998; Padilla \& Perez 2003) but Korb shows how migrants can become stigmatized in their own country of origin. The author strives to demonstrate how the negative image is accompanied by a low public interest in the problems of the representatives of the eastern diaspora. However, the article also sheds light on the relationship between the researcher and his/ her subject. In the course of long-term communication, the researcher as an outsider can shift more and more into the insider's position and as a result he/ she can become a spokesperson for the subject in society. Korb's paper impels for reflection on whether the close relationship that during long-term fieldwork often develops between researchers and their subjects, promotes or hinders the researcher's objectivity. 
As Stephan Steiner, whose essay concludes the first part of the special issue, has noted, for historians in the field of contemporary history, forced migration in Europe usually associates with the totalitarianism of the twentieth century. However, looking back in the history reveals that the roots of this legacy are actually in the population policies that various countries gradually began to practice already in the late Middle Ages. According to Steiner, in the early modern period, a large part of Europe was in the grip of the "deportation frenzy". Public debate over deportation took place in the eighteenth and nineteenth centuries, conferences were held and resolutions were signed, and pro et contra treatises were published; the bibliographical list presented by Steiner (2015: 117) is remarkable. Since that time different problems connected with migration, both forced and voluntary, have been part of the agenda of scientific debates with varying intensity, depending on the intensity of migration processes. Because of the migration crisis of 2015, forced migration has once more become a highly topical issue - in the media, peoples' homes, art exhibitions, documentaries, and certainly in scientific studies. Inspired by the debates circulating around the current migration crisis and based on his deep knowledge on the field, Steiner in his essay "Deportation and the Crises of [Early Modern] Europe: A Brief Historical Introduction" outlines the prehistory of deportation as an avant-garde demographic policy, the aim of which was, first and foremost, to clean certain territories from "unwanted elements". Steiner demonstrates the outstanding progress of forced migration practices based on three examples: (1) the degredado or mass deportation system which functioned in the Portuguese sphere of influence as an epiphenomenon of the colonialism era that began in the fifteenth century, (2) dispersion of Moriscos, who were descendants of the Spanish Muslim population, and their subsequent deportation to North Africa and France in the seventeenth century, and (3) a large-scale population transfer in the Habsburg Empire known as Deportation on the Waterway in the eighteenth century. In his essay, Steiner argues that the roots of the crisis we have to face today, and the ways "how we came to where we are" can be traced back to the past practices of forced migration.

\section{ACKNOWLEDGEMENTS}

The article was supported by the research grant of the Estonian Literary Museum EKM 8-2/20/1 and by the Centre of Excellence in Estonian Studies (TK 145) through the European Regional Development Fund. 


\section{NOTES}

1 As a result of the Great Northern War, the territory inhabited by Estonians was incorporated into the Russian Empire; Estonia remained part of the Empire until 1918, when the Republic of Estonia was founded.

\section{REFERENCES}

Anderson, Sally 2015. Sociability: The Art of Form. In: Vered Amit (ed.) Thinking Through Sociality: An Anthropological Interrogation of Key Concepts. Oxford \& New York: Berghahn, pp. 97-127.

Brah, Avtar 1996. Cartographies of Diaspora: Contesting Identities. New York \& London: Routledge.

Brettell, Caroline B. 2015 [2000]. Theorizing Migration in Anthropology: The Cultural, Social, and Phenomenological Dimensions of Movement. In: Caroline B. Brettell \& James F. Hollifield (eds.) Migration Theory: Talking Across Disciplines. Third edition. New York \& London: Routledge, pp. 148-149.

Brettell, Caroline B. \& Hollifield, James F. (eds.) 2015a [2000]. Migration Theory: Talking Across Disciplines. Third edition. New York \& London: Routledge.

Brettell, Caroline \& Hollifield, James 2015b [2000]. Introduction. Migration Theory: Talking Across Disciplines. In: Caroline Brettell \& James Hollifield (eds.). Migration Theory: Talking Across Disciplines. Third edition. New York \& London: Routledge, pp. 1-36.

Brown, Lisa M. 1998. Ethnic Stigma as a Contextual Experience: A Possible Selves Perspective. Personality \& Social Psychology Bulletin, Vol. 24, No. 2, pp. 163-172. https://doi.org/10.1177/0146167298242005.

Čiubrinskas, Vytis 2018. Transnationalisme et fragmentation identitaire. La citoyenneté culturelle et le capital social postsocialiste des migrants lituaniens aux ÉtatsUnis. [Transnationalism and Fragmentation of Belonging: Cultural Citizenship and Post-Socialist Social Capital among the Lithuanian Immigrants in the USA.] Ethnologie française, Vol. 2, No. 170, pp. 319-328.

Čiubrinskas, Vytis 2020. Uncertainties of Transnational Belonging: Homeland Nationalism and Cultural Citizenship of Lithuanian Immigrants in the USA. Folklore: Electronic Journal of Folklore, Vol. 78, pp....

Clifford, James 1997. Routes: Travel and Translation in the Late Twentieth Century. Cambridge, MA: Harvard University Press.

Cohen, Robin 1997. Global Diasporas: An Introduction. Seattle: University of Washington Press.

Cohen, Robin 2008. Global Diasporas: An Introduction. Second edition. New York \& London: Routledge.

Coming Home Soon: The Refugee Children of Geislingen. Dir. Helga Merits. Merits Productions, 2018. DVD.

Dufoix, Stephane 2008. Diasporas. Oakland, CA: University of California Press.

Eckehart, M. (pseudonym) 2017. How Sweden Became Multicultural. Helsingborg, Sweden: Logic Förlag (e-book). 
Faist, Thomas 2013.Transnationalism. In: Steven J. Gold \& Stephanie J. Nawyn (eds.) The Routledge International Handbook of Migration Studies. New York \& London: Routledge, pp. 449-459.

Favell, Adrian 2015 [2000]. Migration Theory Rebooted? Asymmetric Challenges in a Global Agenda. In: Caroline B. Brettell \& James F. Hollifield (eds.) Migration Theory: Talking Across Disciplines. Third edition. New York \& London: Routledge, pp. 318-328.

FitzGerald, David Scott 2015 [2000]. The Sociology of International Migration. In: Caroline B. Brettell \& James F. Hollifield (eds.) Migration Theory: Talking Across Disciplines. Third edition. New York \& London: Routledge, pp. 115-147.

Gilroy, Paul 1993. The Black Atlantic: Modernity and Double Consciousness. Cambridge, MA: Harvard University Press.

Glick Schiller, Nina \& Basch, Linda \& Blanc-Szanton, Christina 1992. Towards a Transnational Perspective on Migration: Race, Class, Ethnicity and Nationalism Reconsidered. New York: New York Academy of Sciences.

Gold, Steven J. \& Nawyn, Stephanie J. 2013. Introduction. In: Steven J. Gold \& Stephanie J. Nawyn (eds.) Routledge International Handbook of Migration Studies. New York \& London: Routledge, pp. 1-8.

Harzig, Christiane \& Hoerder, Dirk 2009. What is Migration History? Cambridge: Polity Press.

Hazans, Mihails 2003. Commuting in the Baltic States: Patterns, Determinants and Gains. ZEI Working Paper, No. B 02-2003. Rheinische Friedrich-WilhelmsUniversität Bonn, Zentrum für Europäische Integrationsforschung (ZEI), Bonn. Available at https://www.econstor.eu/bitstream/10419/39596/1/365468118.pdf, last accessed on 9 March 2020.

Hirsch, Marianne 1997. Family Frames: Photography, Narrative, and Postmemory. Cambridge, MA: Harvard University Press.

Hirsch, Marianne 2012. The Generation of Postmemory: Writing and Visual Culture After the Holocaust. New York: Columbia University Press.

Hollo, Maarja 2020. Traces of Trauma in Estonian Women's Life Narratives of World War II. Folklore: Electronic Journal of Folklore, Vol. 78, pp....

Jürgenson, Aivar 2015. Etniline ja rahvuslik: Etnokultuurilistest protsessidest eesti idadiasporaas. [Ethnic and National: Ethnocultural Processes in the Estonian Eastern Diaspora.] Acta Historica Tallinnensia, Vol. 21, No. 1, pp. 23-50. DOI: $10.3176 /$ hist.2015.1.02.

kultuur.err.ee 2019 = Dokumentalist Helga Merits: on palju teemasid, millest teise maailmasõjaga seoses veel ei räägita. [Documentary Filmmaker Helga Merits: There Are Many Topics That Are Not Yet Discussed in Connection with World War II.] 6 February. Available at https://kultuur.err.ee/907976/dokumentalisthelga-merits-on-palju-teemasid-millest-teise-maailmasojaga-seoses-veel-eiraagita, last accessed on 5 March 2020.

Kulu, Hill 1997. Eestlaste tagasiränne 1940-1989 Lääne-Siberist pärit eestlaste näitel. [Estonian Return Migration 1940-1989: A Case of West-Siberian Estonians.] Tartu: Tartu Ülikooli Kirjastus.

Kyntäjä, Eve 1997. Eestlased Soomes - akulturatsioonipsühholoogia ja etniline identiteet. [Estonians in Finland - Acculturation Psychology and Ethnic Identity.] In: Hill 
Kulu \& Katrin Metsis \& Tiit Tammaru (eds.) Eestlane olla... eesti keele ja kultuuri perspektiivid. Tartu: Tartu Ülikooli Kirjastus, pp. 60-70.

Levitt, Peggy \& Glick Schiller, Nina 2004. Conceptualizing Simultaneity: A Transnational Social Field Perspective on Society. International Migration Review, Vol. 38, No. 3, pp. 1002-1039. https://doi.org/10.1111/j.1747-7379.2004.tb00227.x.

Long, Nicholas J. \& Moore, Henrietta 2013. Introduction: Sociality's New Directions. In: Nicholas J. Long \& Henrietta L. Moore (eds.) Sociality: New Directions. Oxford \& New York: Berghahn, pp. 1-24.

Markov, Ivaylo 2020. The Kosovo Conflict and the Changing Migration Patterns of the Gorani Community: Continuities and Shifts. Folklore: Electronic Journal of Folklore, Vol. 78, pp....

McDowell, Linda 2013. Working Lives: Gender, Migration and Employment in Britain, 1945-2007. London: Wiley-Blackwell.

Migration Data Portal. Available at https://migrationdataportal.org/?i=stock_ abs_\&t=2019, last accessed on 6 March 2020.

Padilla, Amado M. \& Perez, William 2003. Acculturation, Social Identity, and Social Cognition: A New Perspective. Hispanic Journal of Behavioral Sciences, Vol. 25, No. 1, pp. 35-55. https://doi.org/10.1177/0739986303251694.

Pileva, Desislava 2017. Images of 'Our Foreign Friends': Representations of Students from the Middle East and Africa in the Bulgarian Newspaper 'Student's Tribune' (1960s-1970s). Anthropology, Vol. 4, pp. 47-62. Available at http://anthropologyjournal.org/wp/category/journal/vol-4-2017, last accessed on 9 March 2020.

Pileva, Desislava 2020. From Mobility of 'Exile'. Shifting Co-Presence: Narratives of Bulgarian-Syrian Families in Bulgaria. Folklore: Electronic Journal of Folklore, Vol. 78, pp. ...

Portes, Alejandro \& Guarnizo, Luis E. \& Landolt, Patricia 1999. The Study of Transnationalism: Pitfalls and Promises of an Emergent Research Field. Ethnic and Racial Studies, Vol. 22, No. 2, pp. 217-237. https://doi.org/10.1080/014198799329468.

Quayson, Ato \& Daswani, Girish 2013. Introduction. Diaspora and Transnationalism: Scapes, Scales, and Scopes. In: Ato Quayson \& Girish Daswani (eds.) A Companion to Diaspora and Transnationalism. Chichester: Wiley Blackwell, pp. 1-26.

Raag, Raimo 2004. The National Identity and Culture of Estonians Living in the West 1944-1991. In: Jean-Jacques Subrenat (ed.) Estonia: Identity and Independence. Amsterdam \& New York: Rodopi, pp. 179-197.

Runcis, Maija 2020. Estonian Diaspora in Sweden: An Analysis of the Collection 'Life Destinies' at the Swedish Nordic Museum. Folklore: Electronic Journal of Folklore, Vol. 78, pp. ...

Safran, William 1991. Diasporas in Modern Societies: Myths of Homeland and Return. Diaspora: A Journal of Transnational Studies, Vol. 1, No. 1, pp. 83-99. https: / / doi.org/10.1353/dsp.1991.0004.

Sirkeci, Ibrahim \& Iosifides, Theodoros \& DeTona, Carla \& Frisina, Annalisa (eds.) 2019. Reader in Qualitative Methods in Migration Research. London, UK: Transnational Press London.

Steiner, Stephan 2015. Austria's Penal Colonies: Facts and Visions. In: Vivien Miller \& James Campbell (eds.). Transnational Penal Cultures: New Perspectives on Discipline, Punishment and Desistance. London \& New York: Routledge, pp. 115-126. 
Stierstorfer, Klaus \& Wilson, Janet 2018. General Introduction. In: Klaus Stierstorfer \& Janet Wilson (eds.) The Routledge Diaspora Studies Reader. New York \& London: Routledge, pp. xiii-xxv.

Telve, Keiu 2017. The Impact of Commuting on Close Relations: Case Study of Estonian Men in Finland. In: Elisabeth Boesen \& Gregor Schnuer (eds.) European Borderlands: Living with Barriers and Bridges. London \& New York: Routledge, pp. 110-122.

Toren, Christina 2012. Imagining the World That Warrants Our Imagination: The Revelation of Ontogeny. The Cambridge Journal of Anthropology, Vol. 30, No. 1, pp. 64-79. http://dx.doi.org/10.3167/ca.2012.300107.

Vargas-Silva, Carlos (ed.) 2012. Handbook of Research Methods in Migration. Cheltenham: Edward Elgar.

Vertovec, Steven 2007. Introduction: New Directions in the Anthropology of Migration and Multiculturalism. Ethnic and Racial Studies, Vol. 30, No. 6, pp. 961-978. https: / / doi.org / 10.1080/01419870701599416.

Vertovec, Steven 2009. Transnationalism. New York \& London: Routledge.

Werbner, Pnina 2013. Migration and Transnational Studies: Between Simultaneity and Rupture. In: Ato Quayson \& Girish Daswani (eds.) A Companion to Diaspora and Transnationalism. Chichester: Wiley Blackwell, pp. 106-124.

White, Michael J. (ed.) 2016. International Handbook of Migration and Population Distribution. New York: Springer.

Wimmer, Andreas \& Glick Schiller, Nina 2002. Methodological Nationalism and Beyond: Nation-State Building, Migration and the Social Sciences. Global Networks, Vol. 2, No. 4, pp. 301-334. https://onlinelibrary.wiley.com/doi/abs/10.1111/14710374.00043 .

Triinu Ojamaa is senior research fellow $(\mathrm{PhD})$ at the Estonian Literary Museum, Estonia, and, together with Leena Kurvet-Käosaar, the leader of the research group on migration and diaspora studies of the Centre of Excellence in Estonian Studies. Her main research areas are diasporic identity, adaptation strategy, and inter-ethnic relations in diaspora communities.

triinu.ojamaa@kirmus.ee

Leena Kurvet-Käosaar is associate professor of cultural theory $(\mathrm{PhD})$ at the University of Tartu, Estonia, senior research fellow at the Estonian Literary Museum and, together with Triinu Ojamaa, the leader of the research group on migration and diaspora studies of the Centre of Excellence in Estonian Studies. Her main research areas include life-writing studies, migration studies, personal narratives of Soviet deportations and the Gulag, and trauma studies.

leena.kurvet-kaosaar@ut.ee 